\title{
The Role of Academic Leaders in Private Jordanian Universities in Creating Competitive Environments in Their Universities According to the Strategic Condition Matrix (ADL Matrix)
}

\author{
Dr.Fatima Bufteen Dr.Amal Shakhatreh
}

\begin{abstract}
The present study aimed at identifying the role of academic leaders in private Jordanian universities in creating competitive environments in their universities according to The Strategic Condition Matrix (ADL Matrix). The study population consisted of all academic leaders in private Jordanian universities in the academic year (20192020), whereas the study sample consisted of (105) academic leaders. It was found that the status quo of competitive environments in private Jordanian universities according to The Strategic Condition Matrix (ADL Matrix) from academic leaders' point of view for the institution's competitive position, and the institution's maturity and development in providing services dimensions was moderate. It was also found that there were no significant differences between the estimations of the study sample on the status quo in creating competitive environments in the private Jordanian universities according to The Strategic Condition Matrix (ADL Matrix) from academic leaders' point of view that is attributed to the Region variable. It was found that there were no significant differences between the estimations of the study sample attributed to the respondent's position. Based on the results, several recommendations were suggested such as adopting contemporary administrative concepts in universities' management at various levels, for example: Quality Management, Knowledge Management, Labour Engineering, this will lead to upgrading the overall and main university functions and direct them towards competitiveness.
\end{abstract}

Keywords: Competitiveness, Private Universities, Academic Leaders, The Strategic Condition Matrix (ADL Matrix)

DOI: $10.7176 / \mathrm{JEP} / 11-26-13$

Publication date:September $30^{\text {th }} 2020$

\section{Introduction}

Higher education, through its different institutions such as universities, colleges, and higher institutes in addition to scientific research centres, is considered the leader of the scientific progress movement and the civilizational prosperity in various fields. It has a prominent role in building individuals scientifically and in preparing them professionally and on an educational level, to be able to lead the movement of life and the development in society, as countries connect their hopes and aspirations to it for their progress and for the advancement of their societies. Furthermore, university education has received increasing attention in many societies, which led to competition between them. Higher education has become one of the most important means used by countries to solve their social, economic and political issues and to achieve prosperity and progress, as it is one of the main tools used in preparing and developing trained manpower who are capable of achieving progress and societal development.

Competition among universities is a very positive phenomenon produced by many contemporary factors, which include globalization, knowledge economy, quality standards, global university rankings, and many other factors. It is also an indicator of the strong economy of any country as it is all about being efficient and effective in achieving comprehensive societal development. This means that universities should take care of its educational system, work on reforming it and improving it, periodically. The competition between universities leads to establishing competitiveness that enables them to achieve a competitive advantage among other universities in terms of attracting better human resources, creating the most prominent scientific specializations and creating an academic environment through its physical, financial, moral and cognitive components and contents. (Shamat, 2020, p. 29)

Competition in knowledge economy societies, in its essence, is an educational competition and a race in education. As countries progress through education and activate their outputs to bring in comprehensive societal development and to make huge growth leaps in economy, military and politics, so that any society that is seeking development, competition and excellence becomes obligated to review and reform its educational systems, especially higher education institutions. Lamia Ahmed (2004, p. 64) pointed out in the study she conducted, that the new context of global transformations and the knowledge economy has emphasized on the importance of providing competitive advantages among universities to be the best, allowing them to attract the best human elements from faculty, administrators and students, in order to start a status of competition between universities to create strategic changes in their physical and cognitive structure so that they can achieve a competitive advantage and win the competition race over other universities. It must be realized that education is the cornerstone of competitiveness in the twenty-first century. The fundamental transformations in the economy require creative 
policies to create a connection between education and competitiveness. The educational system is the key challenge for building competitive capabilities of countries in the twenty-first century

Looking at the competitive advantage, that had an important status in both strategic management and business economics, there were many models aimed at improving the services and the product provided, including The Strategic Condition Matrix (ADL Matrix), which was developed by Arthur D. Little for Consultations. This model is based on two main dimensions (The institution's competitive position, and the institution's maturity and development in providing services). (Russell, 2014, p.24).

Regarding the importance of higher education in the Hashemite Kingdom of Jordan, the Jordanian universities are of great importance and an important resource in preparing and developing trained manpower who are capable of making progress and societal development; The competitive advantage of universities establishes the important strategic element that helps in investing opportunities, and provides a real and fundamental opportunity for the institution to achieve continuous progress compared to its competitors. Competitiveness is the source that strengthens the institution's position by achieving profitable returns through its excellence.

\section{Statement of the problem and study's questions:}

It is noted that university education in Jordan expanded in a substantial way, particularly from a quantitative aspect, this is due to a number of social, economic, political, and cultural factors and variables. Since the number of private Jordanian universities has increased significantly in the recent years, great improvements also occurred in a number of Jordanian universities in a few years, and because of universities important roles and responsibilities, as well as the hopes connected to them, there has been a necessity to ensure the success of these universities and their competitiveness to be able to perform the designated roles and fulfill their mission to the fullest, nevertheless, the status que indicates the absence of most of private Jordanian universities from international rankings such as QS and Shanghaied, they are even absent from the Arabic Countries ranking.

Based on the above-mentioned information, the study's problem is represented by the following questions: Q1. What is the status quo in creating competitive environments in the private Jordanian universities according to The Strategic Condition Matrix (ADL Matrix) from the point of view of academic leaders?

Q2. Are there significant differences at $(\alpha=0.05)$ in the status quo in creating competitive environments in the private Jordanian universities according to The Strategic Condition Matrix (ADL Matrix) from the point of view of academic leaders that can be attributed to region and position?

\section{Study's objectives}

The study aimed at identifying the role of academic leaders in private Jordanian universities in creating competitive environments in their universities according to The Strategic Condition Matrix (ADL Matrix).

\section{Study's significance}

- Hopefully, the present study will enable the following authorities to benefit from its results:

- Private Jordanian universities: By identifying the role of academic leaders in private Jordanian universities in creating competitive environments in their universities according to The Strategic Condition Matrix (ADL Matrix).

- Educational leaders: It is reflected in the strengthening of academic leaders' roles in private Jordanian universities in creating competitive environments in their universities according to The Strategic Condition Matrix (ADL Matrix).

- Researchers, scholars, and graduate students who are interested in this field.

\section{The study's definitions:}

\subsection{Academic leaders.}

Procedural definition: A group of academic people entrusted with administrative work in Jordanian universities who are the dean, vice dean, assistant dean, and head of department.

\subsection{Competitiveness:}

The ability of universities to provide high-quality educational and research services for their graduates and faculty, which impacts them positively, they will also gain competitive capabilities and advantages in the labour market at its various levels, at the same time, this impacts society's confidence in universities and consequently, cooperates with them, It will also lead to increasing the demand and enrolment, thus the desired goal has been achieved as the university serves the society, and vice versa. On the other hand, universities compete to achieve the best in their main educational functions, scientific research, community service and reaching international standards, (Rady,2015, p. 5)

Procedural definition:The degree obtained by university professors on the questionnaire of the status quo in creating competitive environments in the private Jordanian universities according to The Strategic 
Condition Matrix (ADL Matrix) for the institution's competitive position, and the institution's maturity and development.

\subsection{Strategic Condition Matrix (ADL Matrix):}

A matrix developed by Arthur D. Little that contributes to finding the strategic status in an institution based on two dimensions: the competitive position and the level of maturity of the institution.

\subsection{Private universities:}

Institutions of higher education that are not run by governments, even though many of these institutions receive public subsidies, especially in the form of tax exemptions, student loans, and public grants.

\section{Study's limits:}

- Human limits: This study sampled all academic leaders in private Jordanian universities which were 478

- Spatial limits: This study was conducted at private Jordanian universities

- Temporal limits: This study was conducted during the academic year 2019/2020.

\section{Previous Studies:}

Al-Ayoubi (2020) aimed at identifying the impact of implementing the dimensions of the Blue Ocean Strategy on achieving competitive advantage in Palestine Technical College - Deir Al-Balah. The researcher adopted the descriptive and analytical method, and the questionnaire was used as a main tool for collecting data. It was found that the status quo in implementing Blue Ocean Strategy was high with a relative weigh of (57.71\%), also the level of competitive advantage was high with a relative weigh of $(97.71 \%)$. It was recommended that there is a necessity to strengthen the role of Blue Ocean Strategy with its dimensions, and to maintain using it by the researched College and in a good manner. Furthermore, it was recommended that colleges that intend to implement Blue Ocean Strategy should also take into account the four dimensions of this strategy and adapt them to the status quo in the changing environment of these colleges.

Al-Ayasrah and Tanash (2017), aimed at identifying the status quo in the competitive advantage in Jordanian public universities according to the contemporary administrative trends. To achieve the objectives of the study, a questionnaire was developed, its validity and reliability were confirmed, and then it was distributed to the study sample that consisted of 304 faculty members. The study relied on the descriptive survey method in all its data. It was found that the degree of estimating the status quo in the competitive advantage in the Jordanian public universities from the point of view of the study sample individuals was moderate. It was also found that there were significant differences attributed to the effect of nature of work in all fields variable and in the total of the status quo.

Al-Ibrahimi (2009), aimed at identifying the degree of effectiveness of evaluating faculty members in Jordanian universities in order to achieve the competitive advantage for their universities, it also aimed at identifying the degree of differences in viewpoints according to the university, academic rank, specialization and experience variables' differences. The study population consisted of the teaching staff in four Jordanian universities who possess a degree (professor, associate professor, and assistant professor), the sample was selected through cluster random method. To achieve the objectives of the study, a questionnaire was developed. It consisted of (26) statements distributed into (3) main dimensions: The Strategic Goals, The University Goals, and The Goals of the Employees. It was found that most of the faculty responses in regard to evaluating performance was moderate, it was also found that there were differences in the estimations of the faculty members that can be attributed to the Position variable in which it came in favor of professors, and to the Specialization variable in which it came in favor of humanities faculties, however, there were no differences in the estimations of the teaching staff according to differences in universities and experiences.

\section{Study's Approach:}

Descriptive survey approach was adopted to identify the role of academic leaders in private universities in creating competitive environments in their universities according to ADL Matrix.

\section{Study's Population and Society:}

The population is represented by all academic leaders in the private Jordanian universities, which were (478). A sample was selected through stratified random sampling method. Data about that is displayed below in table (1) 
Table (1): Distribution of the study's respondents in accordance with (region and position)

\begin{tabular}{|l|l|r|r|}
\hline Variable & Category & Frequency & Percentage \\
\hline Region & Northern & 47 & $44.8 \%$ \\
\cline { 2 - 4 } & Central & 43 & $41.0 \%$ \\
\cline { 2 - 4 } & Southern & 15 & $14.3 \%$ \\
\cline { 2 - 4 } & Total & 105 & $100 \%$ \\
\hline \multirow{5}{*}{ Position } & Dean & 15 & $14.3 \%$ \\
\cline { 2 - 4 } & Vice Dean & 22 & $21.0 \%$ \\
\cline { 2 - 4 } & Assistant Dean & 16 & $15.2 \%$ \\
\cline { 2 - 4 } & Head of Department & 52 & $49.5 \%$ \\
\cline { 2 - 4 } & Total & 105 & $100.0 \%$ \\
\hline
\end{tabular}

\section{Study's Instrument:}

To achieve the objectives of the study, a questionnaire was developed. This questionnaire consisted of (2) dimensions and (27) statements. These dimensions were: The institution's competitive position, and the institution's maturity and development in providing services.

\section{Validity of the Instrument:}

To measure the validity of the questionnaire, Content Validity method was used. The initial questionnaire was passed to (7) experts in Educational Administration and General Administration from universities' faculty. Based on their feedback, modifications and adjustments were adopted.

\section{Reliability of the questionnaire:}

To measure the reliability of the questionnaire, Cronbach alpha coefficient was used. The values ranged between (0.90 and 0.92). This indicates that the questionnaire has an adequate degree of reliability. Table (2) shows Cronbach alpha coefficient values.

Table (2): Cronbach alpha coefficient values for each dimension

\begin{tabular}{|l|r|r|}
\hline Dimension & Cronbach alpha coefficient & Number of statements \\
\hline The institution's competitive position & 0.90 & 15 \\
\hline $\begin{array}{l}\text { The institution's maturity and development } \\
\text { in providing services }\end{array}$ & 0.92 & 12 \\
\hline
\end{tabular}

\section{Criteria for classifying means:}

In order to describe the results, a response ladder was adopted using the following formula:

(Highest limit of scale (5) - Lowest limit of scale (1)) /3

$(5-1) / 3=1.33$

1.00 - 2.33: low 2.34 - 3.67: moderate3.68 - above: high

\section{Study's variables:}

The present study included the following variables:

- Independent variables: Region and Position

- Dependent variables: The role of academic leaders in creating competitive environments in their universities.

\section{Statistical analysis:}

Different statistical analysis methods were used to analyze data and to answer the study two questions such as means, standard deviation and two-way MANOVA.

\section{Results and discussion:}

16.1. Results and discussion related to the study's first question: Q1. What is the status quo in creating competitive environments in the private Jordanian universities according to The Strategic Condition Matrix (ADL Matrix) from the point of view of academic leaders?

To answer this question, means and standard deviations for the status quo in creating competitive environments in the private Jordanian universities according to The Strategic Condition Matrix (ADL Matrix) from the point of view of academic leaders were calculated. These values are captured in table (3) below. 
Table (3): The status quo in creating competitive environments in the private Jordanian universities according to The Strategic Condition Matrix (ADL Matrix) from the point of view of academic leaders

\begin{tabular}{|lr|r|l|r|l|l|}
\hline Dimension Number & Rank & Dimension & Mean & Std. & Level \\
\hline & 2 & 1 & $\begin{array}{l}\text { The institution's maturity and } \\
\text { development in providing services }\end{array}$ & 2.92 & 0.205 & Moderate \\
\hline \multicolumn{2}{|r|}{2} & The institution's competitive position & 2.85 & 0.285 & Moderate \\
\hline Total & 1 & 2.84 & 0.280 & Moderate \\
\hline
\end{tabular}

The results of the study showed that the academic leaders 'estimations of the status quo in creating competitive environments in their universities, according to the ADL Matrix is moderate, for both dimensions: The institution's competitive position and ihe institution's maturity and development in providing services.

Means and standard deviations for each statement of each dimension of the study were also calculated. The results are presented in table (4) below:

Table (4): Means and standard deviations for each statement of the questionnaire

\begin{tabular}{|c|c|c|c|c|c|}
\hline $\begin{array}{l}\text { Statement } \\
\text { No. }\end{array}$ & Rank & Statement & Mean & Std & Level \\
\hline \multicolumn{6}{|c|}{ The institution's competitive position } \\
\hline 15 & 1 & $\begin{array}{l}\text { The university establishes a strong position among its } \\
\text { competitors }\end{array}$ & 2.93 & 0.251 & Moderate \\
\hline 14 & 2 & $\begin{array}{l}\text { The university is keen to gain community satisfaction for its } \\
\text { performance }\end{array}$ & 2.90 & 0.308 & Moderate \\
\hline 12 & 3 & The university takes care of the quality of its inputs & 2.82 & 0.387 & Moderate \\
\hline 3 & 4 & The university achieves a level of job security for its employees & 2.81 & 0.502 & Moderate \\
\hline 11 & 5 & The university supports research centres within its campus & 2.80 & 0.402 & Moderate \\
\hline 13 & 6 & The administration has the ability to stand up for its mission & 2.79 & 0.409 & Moderate \\
\hline 4 & 7 & The university has good revenue & 2.77 & 0.576 & Moderate \\
\hline 1 & 7 & $\begin{array}{l}\text { The university administration possesses administrative } \\
\text { independence }\end{array}$ & 2.77 & 0.524 & Moderate \\
\hline 2 & 9 & The university is keen to constantly evaluate its performance & 2.76 & 0.564 & Moderate \\
\hline 6 & 9 & The university actively partners with the private sector & 2.76 & 0.581 & Moderate \\
\hline 8 & 9 & The university is interested in selecting faculty members & 2.76 & 0.564 & Moderate \\
\hline 5 & 12 & $\begin{array}{l}\text { The university applies total quality management mechanisms to } \\
\text { improve education }\end{array}$ & 2.74 & 0.555 & Moderate \\
\hline 10 & 13 & The university translates objectives into action & 2.73 & 0.444 & Moderate \\
\hline 7 & 14 & $\begin{array}{l}\text { The university develops plans to improve its ranking at the local } \\
\text { and global level }\end{array}$ & 2.70 & 0.587 & Moderate \\
\hline 9 & 15 & There is a diversity of income resources at the university & 2.57 & 0.618 & Moderate \\
\hline \multicolumn{3}{|l|}{ Total } & 2.85 & 0.285 & \\
\hline \multicolumn{6}{|c|}{ The institution's maturity and development in providing services } \\
\hline 16 & 1 & The university Legalizes successful experiences in education & 2.94 & 0.252 & Moderate \\
\hline 17 & 2 & $\begin{array}{l}\text { The university provides services that are compatible to the } \\
\text { labour market }\end{array}$ & 2.92 & 0.250 & Moderate \\
\hline 23 & 3 & The university sets a future vision for what it will look like & 2.91 & 0.281 & Moderate \\
\hline 27 & 3 & $\begin{array}{l}\text { Universities offer majors that aligned with the era's } \\
\text { requirements }\end{array}$ & 2.91 & 0.281 & Moderate \\
\hline 24 & 3 & $\begin{array}{l}\text { The university provides advanced tools and technologies in the } \\
\text { educational process }\end{array}$ & 2.91 & 0.281 & Moderate \\
\hline 25 & 3 & $\begin{array}{l}\text { The university is keen to provide a variety of purposeful } \\
\text { services }\end{array}$ & 2.91 & 0.281 & Moderate \\
\hline 20 & 7 & The university offers various training courses for students & 2.89 & 0.320 & Moderate \\
\hline 26 & 7 & The university provides services at affordable prices & 2.89 & 0.320 & Moderate \\
\hline 19 & 7 & The university provides an attractive environment for students & 2.89 & 0.320 & Moderate \\
\hline 22 & 10 & $\begin{array}{l}\text { The university is keen to create suitable environments to provide } \\
\text { its services }\end{array}$ & 2.87 & 0.342 & Moderate \\
\hline 18 & 11 & The university pays attention to professional employees & 2.85 & 0.361 & Moderate \\
\hline 21 & 12 & $\begin{array}{l}\text { The University provide courses for faculty members in their } \\
\text { field of specialty, periodically. }\end{array}$ & 2.84 & 0.370 & Moderate \\
\hline \multicolumn{3}{|l|}{ Total } & 2.92 & 0.205 & Moderate \\
\hline
\end{tabular}


Based on the results shown in table (4),the means for the institution's competitive position dimension are within the range of(2.93-2.57), in which the total means is (2.85) with a standard deviation of (0.285).

Based on the results shown in table (4), the means for the institution's maturity and development in providing services ranged between (2.94-2.84) in which the total means is (2.92) with a standard deviation of $(0.205)$.

16.2. Results and discussion related to the study's second question: Q2. Are there significant differences at $(\alpha=$ $0.05)$ in the status quo in creating competitive environments in the private Jordanian universities according to The Strategic Condition Matrix (ADL Matrix) from the point of view of academic leaders that can be attributed to region and position?

To answer this question, means and standard deviations for the status quo in creating competitive environments in the private Jordanian universities according to The Strategic Condition Matrix (ADL Matrix) from the point of view of academic leaders that can be attributed to region and position were calculated. These values are captured in table (5)

Table (5): Means and standard deviations for each dimension of the questionnaire

\begin{tabular}{|c|c|c|c|c|c|}
\hline Variable & Dimension & Category & Frequency & Means & Std. \\
\hline \multirow[t]{8}{*}{ Region } & \multirow{4}{*}{$\begin{array}{l}\text { The institution's } \\
\text { competitive position }\end{array}$} & Northern & 47 & 2.7766 & .34276 \\
\hline & & Central & 43 & 2.9302 & .17530 \\
\hline & & Southern & 15 & 2.8667 & .29681 \\
\hline & & Total & 105 & 2.8524 & .28524 \\
\hline & \multirow{4}{*}{$\begin{array}{l}\text { The institution's maturity } \\
\text { and development in } \\
\text { providing services }\end{array}$} & Northern & 47 & 2.9574 & .14103 \\
\hline & & Central & 43 & 2.9070 & .22509 \\
\hline & & Southern & 15 & 2.9667 & .12910 \\
\hline & & Total & 105 & 2.9238 & .20547 \\
\hline \multirow[t]{8}{*}{ Position } & \multirow{4}{*}{$\begin{array}{l}\text { The institution's } \\
\text { competitive position }\end{array}$} & Dean & 15 & 2.9000 & .20702 \\
\hline & & Vice Dean & 22 & 2.8636 & .22792 \\
\hline & & Assistant Dean & 16 & 2.8750 & .22361 \\
\hline & & Head of Department & 52 & 2.8269 & .34134 \\
\hline & \multirow{4}{*}{$\begin{array}{l}\text { The institution's maturity } \\
\text { and development in } \\
\text { providing services }\end{array}$} & Dean & 15 & 2.9667 & .12910 \\
\hline & & Vice Dean & 22 & 2.8864 & .26421 \\
\hline & & Assistant Dean & 16 & 2.9063 & .20156 \\
\hline & & Head of Department & 52 & 2.9327 & .19874 \\
\hline
\end{tabular}

Based on the results shown in table (5), there are apparent differences in the means for the status quo increating competitive environments in the private Jordanian universities according to The Strategic Condition Matrix (ADL Matrix) from the point of view of academic leaders that can be attributed to region and position were calculated. To investigate the significance of these differences, two- way MANOVA was conducted. The results are displayed through table (6) below:

Table (6): The results of the two- way MANOVA for each dimension of the variables

\begin{tabular}{|c|c|c|c|c|c|c|}
\hline Variable & Dimension & $\begin{array}{l}\text { Type III Sum } \\
\text { of Squares }\end{array}$ & Df. & $\begin{array}{l}\text { Mean } \\
\text { Square }\end{array}$ & F. & Sig. \\
\hline \multirow{2}{*}{$\begin{array}{l}\text { Region } \\
\text { Wilkes }=0.922 \\
\text { Significance level } \\
=0.106 \\
\mathrm{~F}=1.936^{\mathrm{b}}\end{array}$} & The institution's competitive position & 0.359 & 2 & 0.179 & 2.260 & 0.110 \\
\hline & $\begin{array}{l}\text { The institution's maturity and } \\
\text { development in providing services }\end{array}$ & 0.123 & 2 & 0.061 & 1.418 & 0.247 \\
\hline \multirow[b]{2}{*}{$\begin{array}{l}\text { Position } \\
\text { Wilkes }=0.971 \\
\text { Significance level } \\
=0.836 \\
\mathrm{~F}=0.462^{\mathrm{b}}\end{array}$} & The institution's competitive position & 0.136 & 3 & 0.045 & 0.572 & 0.635 \\
\hline & $\begin{array}{l}\text { The institution's maturity and } \\
\text { development in providing services }\end{array}$ & 0.050 & 3 & 0.017 & 0.385 & 0.764 \\
\hline \multirow[t]{2}{*}{ Error } & The institution's competitive position & 7.536 & 95 & 0.079 & & \\
\hline & $\begin{array}{l}\text { The institution's maturity and } \\
\text { development in providing services }\end{array}$ & 4.107 & 95 & 0.043 & & \\
\hline \multirow[t]{2}{*}{ Total } & The institution's competitive position & 862.750 & 105 & & & \\
\hline & $\begin{array}{l}\text { The institution's maturity and } \\
\text { development in providing services }\end{array}$ & 902.000 & 105 & & & \\
\hline \multirow[t]{2}{*}{ Corrected Total } & The institution's competitive position & 8.462 & 104 & & & \\
\hline & $\begin{array}{l}\text { The institution's maturity and } \\
\text { development in providing services }\end{array}$ & 4.390 & 104 & & & \\
\hline
\end{tabular}


Based on the results shown in table (6), there are no differences in the means of the responses at $(\alpha=0.05)$ for the status quo in creating competitive environments in the private Jordanian universities according to The Strategic Condition Matrix (ADL Matrix) from the point of view of academic leaders that can be attributed to region and position.

\section{Conclusion and Recommendations:}

It was found that the means for the institution's competitive position dimension was (2.85) with a standard deviation of $(0.285)$. This result can be attributed to the university's need to focus on quality services, and to review its physical tributaries, so that the student is not the only physical component. It can be also attributed to the lack of plans and programs that contribute to improving the level of students, faculty and administrative staff.

It was also found that the means for the institution's maturity and development in providing services was (2.92) with a standard deviation of (0.205). This result can be attributed to the lack of participation among universities for the public good. It can be also attributed to attracting competencies and expertise and getting the benefit from them to improve the university's level and its competitiveness.

However, it was found that there are no differences in the means of the responses at $(\alpha=0.05)$ for the status quo in creating competitive environments in the private Jordanian universities according to The Strategic Condition Matrix (ADL Matrix) from the point of view of academic leaders. The result can be attributed to region and position. It can be also attributed to academic leaders in private universities' agreement in all regions on the status quo in creating competitive environments in their universities.

In the light of the study's results, the followings are recommended:

- Promoting the awareness of Ministry of Higher Education towards urging private Jordanian universities to become among competing universities.

- Adopting contemporary administrative concepts in universities' management at various levels, for example Quality Management, Knowledge Management, Labour Engineering, this will lead to upgrading the overall and main university functions and direct them towards competitiveness.

- Linking university education to the requirements of society and its educational, cultural, professional, and developmental needs, and linking them to the status quo in the society and its various issues.

- Conducting more similar studies that researches the status quo in creating competitive environments in our private Jordanian universities and linking them to other variables.

\section{References}

- Ahmed, Lamia Mohamed (2004). The VIrtual University as One of the Educational Formats, The First Annual Conference of the Arab Center for Education and Development "The future of Arab university education, development visions", was held in the period of 3-5 May 2004, Volume 1. Issue 1. pp. 650-651.

- Al-Ibrahimi, Adnan (2009). Degree of Effectiveness of Evaluating Faculty Members in Jordanian Universities to Achieve Competitive Advantage of their Universities, Journal of the Association of Arab Universities and Psychology, Scientific Association of Faculties of Education at the Arab University, Damascus University. Volume 7. Issue 2.

- Al-Ayasrah, Mahmoud and Tanash, Salameh (2017). The Status Quo in Competitive Advantage in Jordanian Public Universities According to Contemporary Administrative Trends, Journal of the Jordanian Educational Society. Volume 2. Issue 1. pp. 179-212

- Al-Ayoubi, Mansour (2020). Blue Ocean Strategy as an Entrance to Achieving Competitive Advantage - An Applied Study in Palestine Technical College - Al Ain University Journal of Business and Law. Volume 2. Issue 4. pp.1-40

- Radi, Mervat Muhammad (2012). A Proposed Scenario for Consolidating the Competitive Advantage in Palestinian Universities, Conference on Arab Regional Competitiveness, Cairo University, Egypt.

- Shamat, Nevin (2010). International Competitiveness and its Impact on Arab and Global Trade. Alexandria: University Education House.

- Qasim, Russell (2014). Management Tools and Business Development Methods, (150) Models and Methodologies in Enterprise Development. Jarir Bookstore. Riyad. 